NBER WORKING PAPER SERIES

\title{
THE STAYING POWER OF STAGGERED WAGE AND PRICE SETTING MODELS IN MACROECONOMICS
}

\author{
John B. Taylor \\ Working Paper 22356 \\ http://www.nber.org/papers/w22356 \\ NATIONAL BUREAU OF ECONOMIC RESEARCH \\ 1050 Massachusetts Avenue \\ Cambridge, MA 02138 \\ June 2016
}

I wish to thank Susanto Basu, John Cochrane, Huw Dixon, Robert Hall, Jim Hamilton, Engin Kara, Pete Klenow, Olivier Musy, Carlos Viana de Carvalho, Harald Uhlig and Carl Walsh for helpful comments. This working paper was prepared for the forthcoming Handbook of Macroeconomics vol. II, and it updates and expands NBER Working Paper No. 6754 issued in October 1998 which was prepared for a chapter in Handbook of Macroeconomics vol. I. The views expressed herein are those of the author and do not necessarily reflect the views of the National Bureau of Economic Research.

NBER working papers are circulated for discussion and comment purposes. They have not been peer-reviewed or been subject to the review by the NBER Board of Directors that accompanies official NBER publications.

(C) 2016 by John B. Taylor. All rights reserved. Short sections of text, not to exceed two paragraphs, may be quoted without explicit permission provided that full credit, including () notice, is given to the source. 
The Staying Power of Staggered Wage and Price Setting Models in Macroeconomics

John B. Taylor

NBER Working Paper No. 22356

June 2016

JEL No. E3,E4,E5

\begin{abstract}
$\underline{\text { ABSTRACT }}$
After many years, many critiques, and many variations, the staggered wage and price setting model is still the most common method of incorporating nominal rigidities into empirical macroeconomic models used for policy analysis. The aim of this chapter is to examine and reassess the staggered wage and price setting model. The chapter updates and expands on my chapter in the 1999 Handbook of Macroeconomics which reviewed key papers that had already spawned a vast literature. It is meant to be both a survey and user-friendly exposition organized around a simple "canonical" model. It provides a guide to the recent explosion of microeconomic empirical research on wage and price setting, examines central controversies, and reassesses from a longer perspective the advantages and disadvantages of the model as it has been applied in practice. An important question for future research is whether staggered price and wage setting will continue to be the model of choice or whether it needs to be replaced by a new paradigm.
\end{abstract}

John B. Taylor

Herbert Hoover Memorial Building

Stanford University

Stanford, CA 94305-6010

and NBER

John.Taylor@stanford.edu 


\section{TABLE OF CONTENTS}

\section{Introduction}

2. An Updated Empirical Guide to Wage and Price Setting in Market Economies

2.1 Microeconomic Evidence on Wage Setting

2.2 Microeconomic Evidence on Price Setting

2.3 Pertinent Facts About Microeconomic Data on Wage and Price Setting

3. Origins of the Staggered Wage and Price Setting Model

4. A Canonical Staggered Price and Wage Setting Model

4.1 Canonical Assumptions

4.2 Two More Equations and a Dynamic Stochastic General Equilibrium Model

4.3 The Policy Problem and the Output and Price Stability Tradeoff Curve

4.4 Key Implications

5. Generalizations and Extensions

6. Derivation of Staggered Price Setting When Firms Have Market Power

6.1 Pass-Through Implications

6.2 Marginal Costs versus the Output Gap

6.3 The Debate Over the Contract Multiplier

7. Price and Wage Setting Together

8. Persistence Questions and Indexing

9. Taylor contracts and Calvo contracts

10. State- Dependent Models and Time-Dependent Models

11. Wage-Employment Bargaining and Staggered Contracts

12. Staggered Contracts Versus Inattention Models

13. Critical Assessment and Outlook

References 


\section{Introduction}

The staggered wage and price setting model has had remarkable staying power. Originating in the 1970s before the advent of real business cycle models, it has been the theory of choice in generation after generation of monetary business cycle models. In their review of over sixty macroeconomic models in their chapter for this Handbook, Wieland, Afanasyeva, Kuete, and Yoo (2016) define three such generations each with representative models that are based on staggered price or wage setting theories. ${ }^{1}$

This chapter examines the role of staggered wage and price setting as a method of incorporating nominal rigidities in empirical macroeconomic models used for policy analysis. It is both an exposition and a survey. It builds on my earlier Handbook of Macroeconomics chapter (Taylor, 1999) which reviewed original research papers that had already spawned a vast literature. It focusses on new research since that Handbook chapter, and, though it is largely selfcontained, a more complete history of thought in this area requires looking at that chapter too. This chapter considers the explosion of microeconomic empirical research on wage and price setting behavior, the main critiques of the model, such as by Chari, Kehoe, and McGrattan (2000), and the complementary work on state-dependent pricing by Dotsey, King, and Wolman (1999) and Golosov and Lucas (2007). Finally, the chapter reassesses from a longer vantage point the advantages and disadvantages of the model as it has been applied in practice, and it considers possible directions for future research.

\footnotetext{
${ }^{1}$ See Wieland et al. (2016), Table 5
} 


\section{An Updated Empirical Guide to Wage and Price Setting in Market Economies}

I started off my 1999 Handbook of Macroeconomics chapter with "an empirical guide to wage and price setting in market economies" noting that "one of the great accomplishments of research on wage and price rigidities in the 1980s and 1990s is the bolstering of case studies and casual impression with the evidence from thousands of observations of price and wage setting collected at the firm, worker or union level.” The same could be said of the new research on microeconomic data during the past two decades except that there is much more of it—a virtual explosion of "Big Data" microeconomic studies, especially in the United States and European countries. These studies have confirmed much of the earlier work, but they have also uncovered new important facts about the timing, frequency, and determinants of price and wage change which are relevant for future research and model building. Accordingly, in this section I give an "updated empirical guide to wage and price setting in market economies"

As a starting point, recall that informal observation informed the original theoretical research on staggered wage and price setting models in the 1970s since there was virtually no microeconomic empirical research to guide it. ${ }^{2}$ For many firms and organizations, whether in a formal employment contract or not, wages—including fringe benefits—appeared to be adjusted about once per year after a performance review and after consideration of prevailing wages in the market. A large fraction of the wage payment appeared to be a fixed amount, though overtime pay, bonuses, profit sharing, and piece rates were not uncommon, with as many similarities as differences between union and non-union workers. Indexing of wages was seen to be rare in wage setting arrangements of one year or less. And wage adjustments looked to be

\footnotetext{
${ }^{2}$ I will describe the 1970s modeling research in the next section. Informal observation, of course, guided earlier models of price and wage adjustment, going way back to the time of Hume's (1742) classic essay "On Money" in which he wrote "by degrees the price rises, first of one commodity, then of another."
} 
unsynchronized—occurring at different times for different firms throughout the year—though there were exceptions such as the Shunto (spring wage offensive) in Japan.

Regarding prices, research work by Stigler and Kindahl (1970) had begun to document the extent of price rigidity for a wide variety of products and led people to distinguish informally between "auction markets" where prices changed continuously and "customer markets" where they changed infrequently, a terminology coined by Okun (1981). Though online purchasing has begun to blur this distinction, price changes, like wage changes, appeared to be unsynchronized and firms appeared to take the prevailing price of competing sellers into account.

Fortunately, a huge number of microeconomic studies of wage and price setting over the past few decades have given modelers much more to go on than informal observation. I first consider microeconomic empirical research on wage setting and then on price setting.

\subsection{Microeconomic Evidence on Wage Setting}

To my knowledge, the first empirical study to use actual microeconomic wage data to validate or calibrate the staggered wage setting models of the 1970s was my (1983) study using union wage contracting data in the United States. At the time, the Bureau of Labor Statistics had been calculating detailed data on major collective bargaining agreements for about 10 million workers in the United States and publishing the results in Current Wage Developments. The “major” contracts included agreements affecting 1,000 or more workers. Although that sector represented only 10 percent of US employment, it was where the data were, and it was a place to begin.

The data indicated that wage setting was highly non-synchronized, with agreements

spread throughout the year though with relatively more settlements in the $2^{\text {nd }}$ and $3^{\text {rd }}$ quarters. 
Of these 10 million workers only about 15 percent had contract adjustments each quarter and only 40 percent each year. I used these micro data to calibrate a staggered wage setting model with heterogeneous contract lengths and simulated various monetary policies, and in a companion study (Taylor (1982)) I assumed that the remaining workers had shorter contracts. Looking at the unions data over a period of time, Cecchetti (1984) found that the average period between wage changes declined with higher inflation, but was still more than one year during the high inflation period of the 1970s. There were few international comparisons at that time, though Fregert and Jonung (1986) found that wage setting in Sweden was unsynchronized and that contract length decreased with higher inflation, but it never dropped below one year on average.

There was then a lull in research on microeconomic wage setting practices, perhaps due to the increased interest in real business cycles and a corresponding "dark age” of research on wage and price rigidities, as I described in Taylor (2007). In any case, a gap was left between macroeconomic models of wage setting and the microeconomic evidence.

An explosion of research since the early 2000s (just after the completion of the Handbook of Macroeconomics, Volume 1!) has gone a long way to filling that gap. An important example, which has contributed greatly to our knowledge of micro wage setting, is the research enabled by the data collected from firms in a survey by the Wage Dynamics Network (WDN). The WDN was created after the founding of the European Central Bank; it consists of researchers at the central banks in the Eurosystem. The WDN surveyed wage and price setting practices at 17,000 European firms. The sample was designed to reflect firm employment size and sector distribution in each country. The survey covered both firms with employees in and out of unions. The percentage of employees in unions varies greatly across countries, ranging from over 
$70 \%$ in Scandinavian countries to less than $10 \%$ in Central and Eastern European countries, France, Spain, a percentage similar to the United States.

The report by Lamo and Smets (2009) summarizes the research on this survey referring to 81 different WDN papers and publications. They report that about 60 percent of the 17,000 firms surveyed change wages once a year, while 26 percent change wages less frequently. The average duration of wages is about 15 months and is longer than the average duration of prices, which is about 9.5 months according to a parallel price setting survey in European countries.

Lamo and Smets (2009) also report "strong evidence of time-dependence in wagesetting” with 55 percent of firms reporting that their wage changes occur in a particular month. ${ }^{3}$ The timing of wage changes is characterized by a mix of staggering and synchronization. Indeed, there is a lot of heterogeneity across countries; the percentage of firms that change wages "more frequently than once a year ranges from $2.6 \%$ in Hungary and $4.2 \%$ in Italy to $33.9 \%$ in Greece and $42.1 \%$ in Lithuania” according to Lamo and Smets.

There is also related time series work for specific European countries. Lünnemann and Wintr (2009), for example, examined monthly micro data from the Luxembourg social security authority. The data are reported by employers about their employees and pertain to the period from January 2001 to December 2006. They report that measurement error biases upwards the frequency of wage change, but adjusting for this measurement error they find a frequency of wage change of 9 percent to 14 percent per month, which is lower than for consumer prices at 17 percent. They also find a great deal of heterogeneity across forms. There is clear timedependence with many wages set around the month of January.

\footnotetext{
${ }^{3}$ Some of the terminology used in this section—such as time-dependence, state dependence, Taylor fixed length contracts, Calvo model-is defined later in the chapter.
} 
Le Bihan, Montornès, and Heckel (2012) examine a time series of French wage data. They use a quarterly panel of 38,000 French establishments with 6.8 million employees. They examine the base wage for 12 employee categories over 1998-2005. They argue that the base wage is a relevant indicator of wages in France because the base wage represents 77.9 percent of gross earnings. Furthermore, most bonuses (like "13th month” payments or holidays bonuses) constitute a fixed part of the earnings (5.2 percent) and are linked to the base wage. The frequency of quarterly wage change is around 38 percent, and in the case of France, there is not much cross-sectoral heterogeneity in wage stickiness.

They estimate a hazard function — the probability of a change in the wage conditional on an unchanged wage spell of a given duration. Their estimates of the hazard function are shown in Figure 1. The authors state that the hazard function has a "noticeable spike at four quarters but is rather flat otherwise" and note that "such a pattern is consistent with the prevalence of Taylorlike, one-year contracts.” 


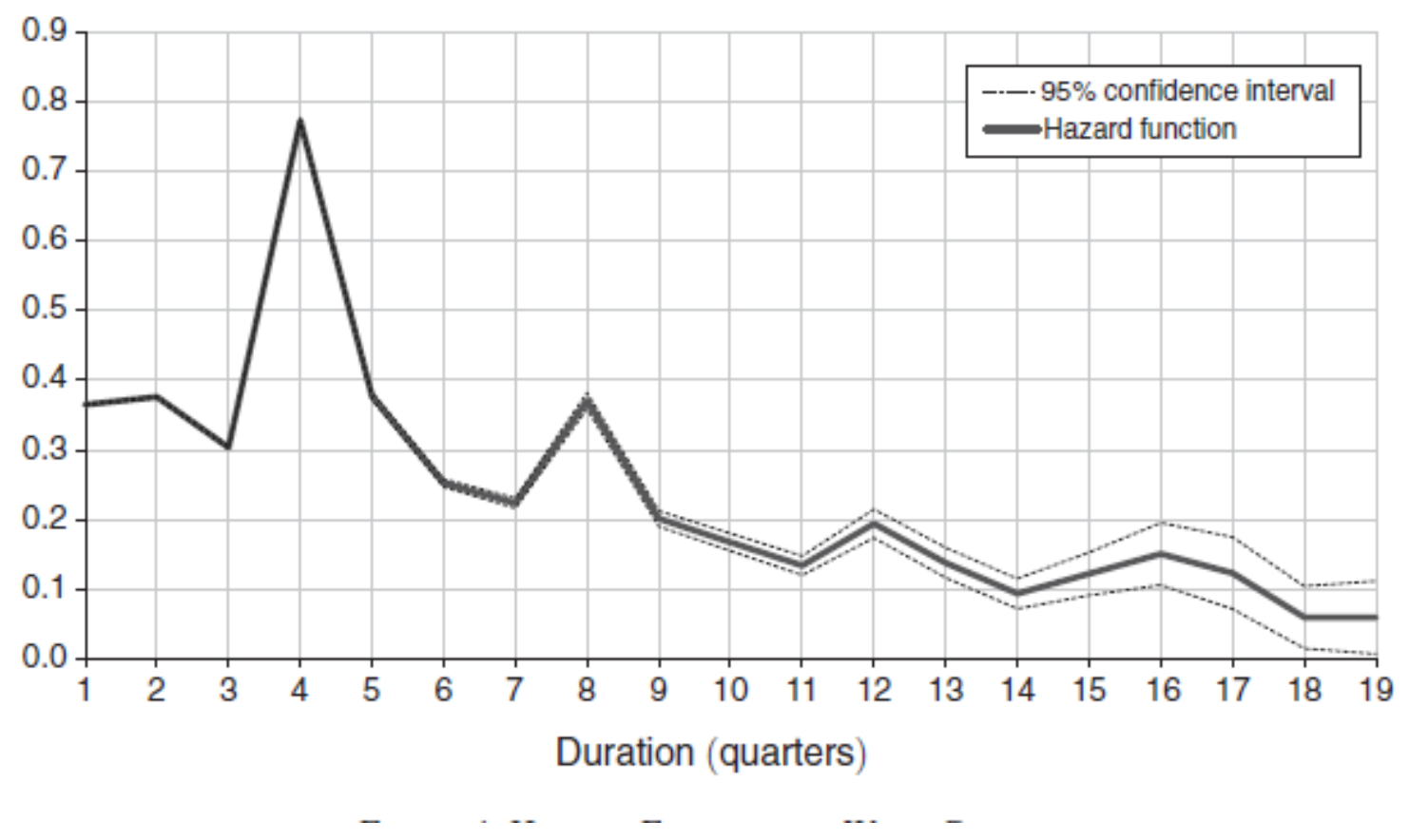

Figure 1. Estimate of the Hazard Function of Wage Change in France Source: Le Bihan, Montornès, and Heckel (2012)

Le Bihan, Montornès, and Heckel (2012) also estimate and report the frequency of wage change each quarter and the variation of that frequency over time. Their estimates are shown in Figure 2 for all wages as well as for wages near the minimum wage. As they argue "there is evidence of a large degree of staggering since the frequency of wage changes is in no quarter lower than 20 percent.” Note that there is some synchronization in the first quarter for all wages and in the third quarter for minimum wages, the later corresponding to the national minimum wage update in France each summer. They also report that their "micro-econometric evidence...suggests wage adjustment is mainly time-dependent in France.” And while wage changes are largely staggered across establishments, the authors report that there is a large degree of synchronization of wage changes within establishments. Avouyi-Dovi et al. (2013) also examine the wage setting process in France. In contrast to Le Bihan et al. (2012), they 
collect and examine data on wage bargaining agreements, as Taylor (1983) did for the United States, but with much more detail. Their data pertain to both firms and industries. They find a sharp peak in the distribution of wage contract durations at 12 months. They also find that that the "hazard rate shows a peak above $40 \%$ at twelve months and remains flat below $10 \%$ elsewhere.” Indeed, their plots of the hazard function look like much like those in Figure 1 in this chapter with even more pronounced peaks. Finally, they find that the "wage change decisions are staggered over the year" with some evidence of seasonality that also shows up in the aggregate data. In many respects the findings Avouyi-Dovi et al. (2013) and those of Le Bihan et al. (2012) are very similar even though they use completely different data sets.

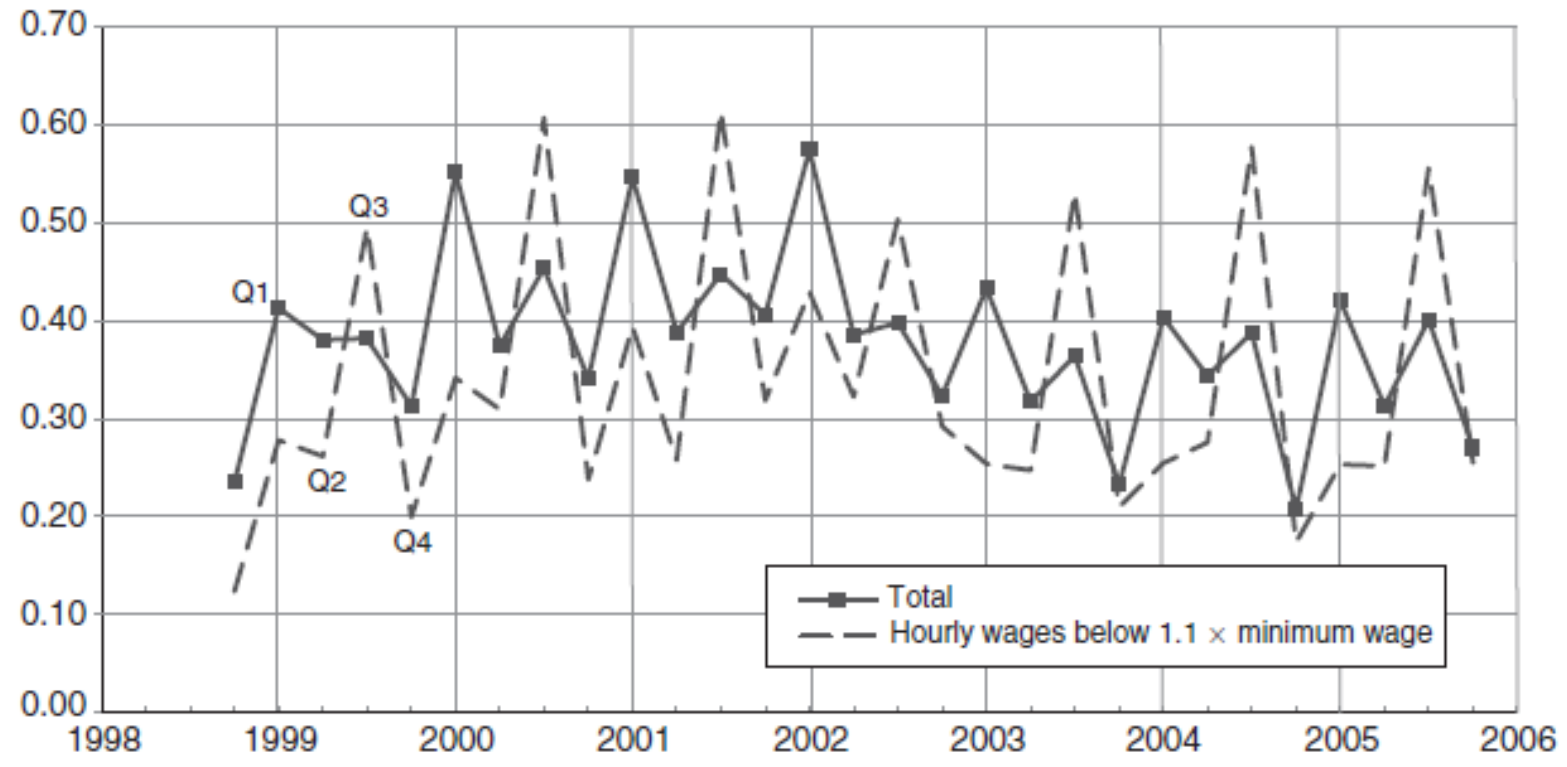

Figure 2. Time Variation in the Frequency of Wage Change by Quarter in France Source: Le Bihan, Montornès, and Heckel (2012) 
Another time series study is the paper by Sigurdsson and Sigurdardottir (2011) which examines wage setting behavior in Iceland. They use a micro wage data set with a monthly frequency for the years 1998-2010. They find that average frequency of wage change is $10.8 \%$ per month. They find that "wage setting displays strong features of time-dependence: half of all wage changes are synchronized in January, but other adjustments are staggered through the year” though later work by Sigurdsson and Sigurdardottir (2016), which focuses more on the global financial crisis, finds more evidence of state dependent wage setting. The authors also estimate a hazard function and find that it has a large spike at twelve months. These facts indicate that, as the authors put it, "wage setting is consistent with the Taylor (1980) fixed duration contract model, but there exist contracts with both shorter and longer duration than precisely one year.”

Recent work by Barattieri, Basu and Gottschalk (2014) has added important time series information about wage setting in the United States. They use high frequency panel data from the Survey of Income and Program Participation (SIPP) which follows people for a period of from 24 to 48 months with interviews every four months. The authors focus on hourly wage data (rather than salaries) which leaves them with a panel of 17,148 people from March 1996 to February 2000. The panel consisted of 49.4 percent women; ages ranged from 16 years to 64 years and the average wage is $\$ 10.03$ per hour. As with individual data reported by Lünnemann and Wintr (2009), the authors found a great deal of measurement error which adds noise to the wage series and effectively reduces the reported time that a wage is fixed. They corrected for this measurement error using structural break tests commonly used in time series analysis to look for big and persistent changes by filtering out smaller and more temporary changes.

They find that the quarterly frequency of wage adjustment, after correcting for measurement error, ranges from 12 percent to 27 percent, which is much lower than the 56 
percent without correction for measurement error. They note that this corrected range is comparable to that found in the European studies reviewed above when reported on a common quarterly frequency:
Lünnemann and Wintr (2009)
19 to 36 percent
Bihan, Montornès, and Heckel (2012)
35 percent
Sigurdsson and Sigurdardottir (2011)
13 to 28 percent

Finally, Barattieri, Basu and Gottschalk (2014) estimate a hazard function for the United States with their date corrected for measurement. Their estimates are shown in Figure 3. There is a sharp peak at twelve months leading the authors to conclude that "Taylor-type fixed-length contracts have stronger empirical support than Calvo-type constant-hazard models.” This corresponds with the time series studies on wage setting in France and Iceland reported above. 


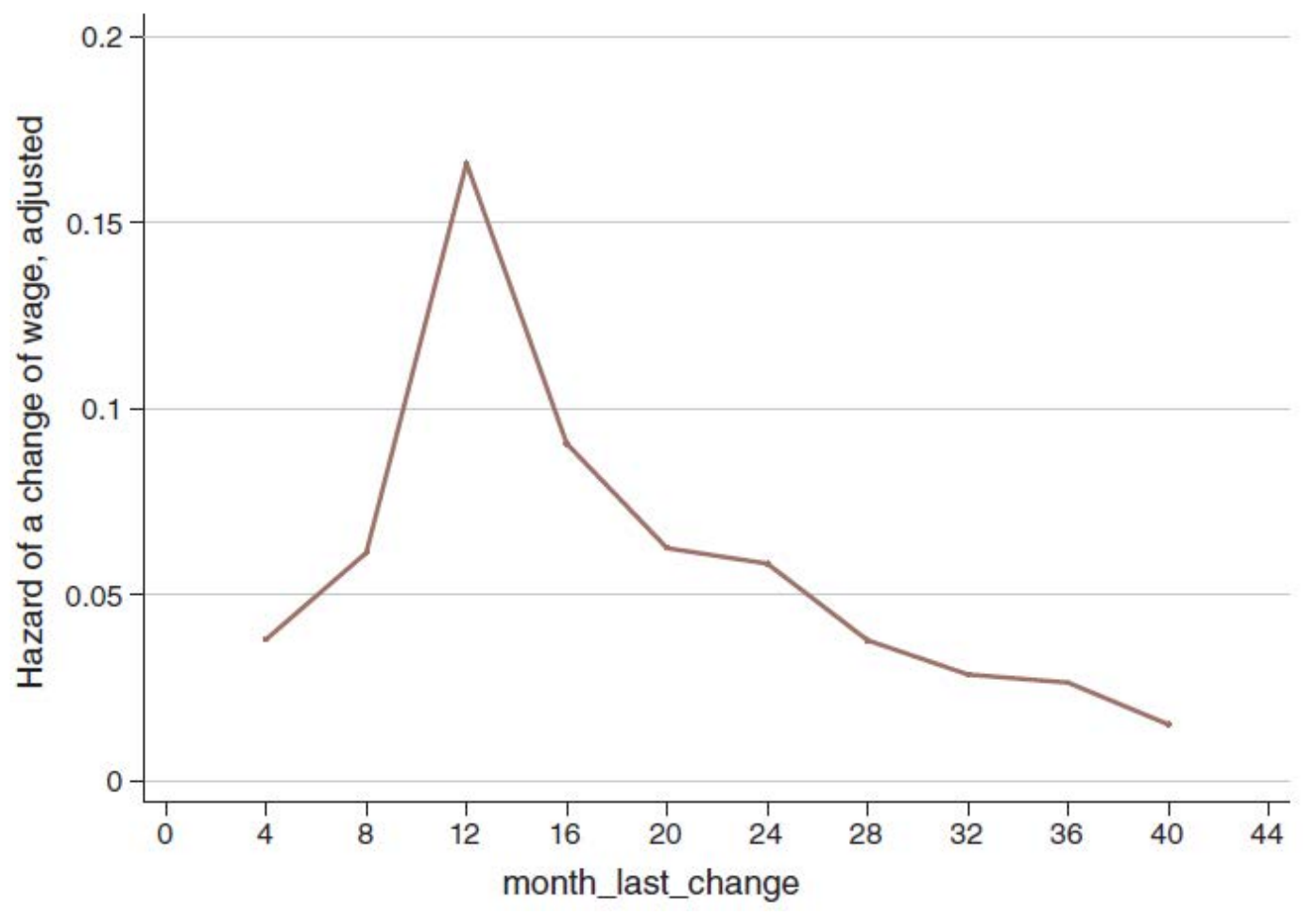

Figure 3 Estimated Hazard Function for a Within Job Wage Change in the United States Source: Barattieri, Basu and Gottschalk (2014)

If some structural assumptions about the general form of wage setting are made, it is also possible to extract information about individual wage setting mechanisms indirectly from the autocorrelation functions of aggregate time series data, as I explained in my chapter in the first Handbook of Macroeconomics with examples of these indirect methods including Backus (1984), Benabou and Bismut (1987), Levin (1991), and Taylor (1993). In a more recent example, Olivei and Tenreyro (2010) show that the impact of monetary policy shocks depends on the timing of wage changes, suggesting that time-dependent wage setting has important macroeconomic implications. They compare the effect of Japan's Shunto with different wage change timing in the United States and Germany, and they show that that the impact of an 
aggregate monetary shock is larger when it occurs at a time when only a few wages are being adjusted. Estimates of time-varying distributions are also reported in Taylor (1993a) to accommodate the Shunto mechanism in Japan.

\subsection{Microeconomic Evidence on Price Setting}

Until the recent explosion of microeconomic research on price setting, the evidence on the prices of particular products showed remarkably long periods of set prices. Carlton (1989) found that the time between adjustment of prices ranged from 14 years for steel, cement, and chemicals to 4 years for plywood and nonferrous metals. Cecchetti (1986) found that the average length of time between price changes for magazines was 7 years in the 1950s and about 3 years in the 1970s. Kashyap (1995) found that mail-order catalog prices were fixed for as long as two years. Blinder et al. (1998) found that about 40 percent of firms change their prices once per year, 10 percent change prices more frequently than once per year; and 50 percent leave their prices unchanged for more than a year. Dutta et al. (2002) found evidence of more frequent price changes for several types of frozen and refrigerated orange juice.

In contrast more recent detailed research by Bils and Klenow (2004), Klenow and Kryvtsov (2008), Nakamur and Steinsson (2008) and the ECB surveys in Europe shows more frequent changes in prices. A very useful review of this research is provided in a chapter in the Handbook of Monetary Economics by Klenow and Malin (2011) so there is no need to summarize it again here. They report that the average time between price changes is every 4 months for items in the Consumer Price Index and every 6 to 8 months for items in the producer price index. However, there is a great deal of heterogeneity across items with service prices changing less rapidly than good prices. They also report that price setting is unsynchronized, a 
finding that also goes back to Lach and Tsiddon (1996) who also noted within-store synchronization. Finally, Klenow and Malin (2011) emphasize that reference prices tend to be changed less frequently than regular prices.

As with wage setting, useful information about price setting in Europe comes from surveys of firms conducted by central banks. Fabiania, Druant, Hernando, Kwapil, Landau, Loupias, Martins, Mathä, Sabbatini, Stahl and Stokman (2006) investigated the pricing behavior of more than 11,000 firms based on a survey conducted by the Eurosystem of national central banks. They found that "price reviews happen with a low frequency, of about one to three times per year in most countries, but prices are actually changed even less.” They also found that "one-third of firms follow mainly time dependent pricing rules, while two-thirds allow for elements of state dependence.” The majority of the firms take into account both past and expected economic developments in their pricing decisions.

\subsection{Pertinent Facts About Microeconomic Data on Wage and Price Setting}

Though it is difficult to glean key facts from so many empirical studies, I would emphasize the following general features of price and wage setting as relevant to theoretical research on models of staggered wages and prices which I will review in the following sections:

(1) Both wage setting and price setting is staggered or unsynchronized over time. Even in unusual situations when there is a specific time of year for changing wages—such as in the spring in Japan and in January in some European counties, there are many other months where wages are changed. An example of evidence for staggered wage setting is that there was not one quarter where the frequency of wage change fell below 20\% in France during the years from 1998 to 2006. Similarly, price changes 
are also typically not synchronized, as Klenow and Malin (2011) emphasize in their review.

(2) There is considerable evidence that most wages are set for a fixed length of time rather than changed at random intervals. The most common interval for wage changes is four quarters or twelve months. In Europe, the WDN survey shows that 60 percent of firms adjust wages once per year. Moreover, when it has been estimated, such as in France and the United States, the hazard function has a sharp peak at four quarters or twelve months.

(3) Wages and prices are set at a constant level during the length of time that they are set, rather than predetermined in advance to increase by certain amounts. Although originally clear from informal observation, this fact was confirmed for prices in empirical work by Klenow and Kryvtsov (2008) and Nakamura and Steinsson (2008). An exception in the case of wages occurs in the case of multiyear union contracts where deferred increases in later years are often agreed to in advance.

(4) There is strong evidence of time-dependence in wage-setting and slightly less in price setting. Regarding wage setting, 55 percent of European firms report that wage changes occur in a particular month. In contrast, one-third of European firms follow "mainly" time dependent pricing practices and two-thirds allow for elements of state dependence.

(5) Wage adjustment is less frequent than price adjustment, according to the most recent microeconomic empirical research, a finding which reverses the order reported in my 1999 Handbook of Macroeconomics chapter. In the European survey, the average duration of wages is greater than the average duration of prices. According to 
Barattieri, Basu and Gottschalk (2014) the quarterly frequency of wage adjustment in the United States, when correcting for measurement error, is much less than the CPI data as summarized by Klenow and Malin (2011). Price and wage rigidities are temporary, but prices and wages do not all change instantaneously and simultaneously, as if determined on a spot market with full information. There is no empirical reason—aside from the need for a simplifying assumption or the desire to illustrate a key point— to build an empirical model in which wages are perfectly flexible (determined on a spot market with full information) while prices are temporarily rigid, or vice versa.

(6) The frequency of wage and price changes depends on the average rate of inflation. While this is a robust finding, it should be emphasized that for the range of inflation rates observed in recent years in the developed economies, the average duration of wages and prices remains high. For a given target inflation rate, constant frequency of price adjustment is a good assumption to make in an empirical or policy model.

(7) There is a great deal of heterogeneity in wage and price setting practices across countries, across firms, across products, and across types of workers. Though the data reveal certain tendencies, as describe in the six points above, there is no practice that applies $100 \%$. Wages in some industries change once per year on average, while in others wages change once per quarter or once every two years. There is a mixture of state-dependence and time-dependence in most countries. The price of services changes less frequently than goods. Wages of unskilled workers change more frequently than for skilled workers. One might hope that a model with homogeneous "representative" price or wage setting would be a good approximation to this more 
complex world, but models with some degree of heterogeneity are needed to describe reality accurately.

\section{Origins of the Staggered Wage and Price Setting Model}

When you look through graduate level textbooks in monetary theory and policy you find that the chapters on modern macro models with nominal rigidities begin with the idea of staggered contracts or staggered wage and price setting that had its origin in the 1970s at about the same time that the idea of rational expectations was being introduced to macroeconomics. Carl Walsh's treatment in his third edition (2010) of “early models of inter-temporal nominal adjustment” starts with—“Taylor’s (1979b, 1980) model of staggered nominal adjustment”—and then goes on to examine the version due to Calvo (1983). David Romer's chapter in his fourth edition (2012) starts off with three modeling frameworks from this period: Fischer-Phelps-Taylor (1977), Taylor (1979b) and Calvo (1983). Likewise, Michael Woodford's (2003) chapter on nominal rigidities is mainly about staggered price or wage setting models that emanate from those days.

It is no coincidence that staggered contract models arose at about the same time as rational expectations was introduced to macroeconomics. Rational expectations meant that one could not rely on slow adjustment of expectations—so-called adaptive expectations—or on ad hoc partial adjustment models as the reason why prices and wages moved sluggishly over time. One had to think more about the economics in modelling the adjustment of prices and wages and the impact of monetary policy.

The earliest work by Fischer (1977), Gray (1976) and Phelps and Taylor (1977) assumed that the price or wage was set in advance of the period it would apply and at a value such that 
markets would be expected to clear. ${ }^{4}$ In other words, prices would be set to bring expected demand into equality with expected supply. In the case of Phelps and Taylor (1977) the price was set one period in advance, and the price could change every period-no matter how short the period — much like in perfectly flexible price models. In the case of Fischer (1977) and Gray (1976) the wage could be set more than one period in advance but at a different level each period, so that expected supply could equal expected demand in every period, again not much different empirically from flexible price models.

In all these models the price or the wage would change continuously, period by period. If the model was quarterly, then the price or wage could change every quarter; if the model was monthly, the price or wage could change every month. However, in the real world prices are set at the same level for more than one period; they usually remain at the same level for several weeks, months or even quarters; and the same is true for wages with the representative period of constancy being about twelve months.

In addition to being inconsistent with the microeconomic data (as later confirmed in formal microeconomic empirical research referred to in the previous section), this type of model was completely inconsistent with the aggregate dynamics of wages, prices or output. I realized this as soon as I tried to bring models along the lines of Phelps and Taylor (1977) to the data. Such models could not come close to generating the time series persistence or auto-correlation that was in real world data. In effect, the price or wage setting assumption in these models was only slightly different from the assumption that prices and wages were market clearing. I proposed the staggered contract model and its key property — the contract multiplier-as a way

\footnotetext{
${ }^{4}$ These researchers were working largely independently of each other even though the papers were eventually published at the same time (and two in the same issue of the Journal of Political Economy). One possible exception was a conversation I had at the time with Stan Fischer who asked me what I was working on. I replied by describing a paper I was working with Phelps on sticky prices and rational expectations. Stan replied that he thought that it was a good topic, but I do not recall that he mentioned that he was working on the topic.
} 
to generate needed persistence and solve this problem. The model was explicitly designed to capture the key characteristics of the micro data and at the same time to match the aggregate dynamics.

\section{A Canonical Staggered Price and Wage Setting Model}

The simplest way to see this is to consider the canonical staggered price setting model illustrated in Figure 4 using a degree of abstraction and simplification similar to expositions of the overlapping generations model. Later in this chapter I will discuss a range of variations and extensions of this simple form. The basic idea of staggered price setting is that firms do not change their prices instantaneously from period to period. Instead there is a period of time during which the firm's price is fixed, and the pricing decisions of other firms are made the same way but at different times. Price setting is thus staggered and unsynchronized.

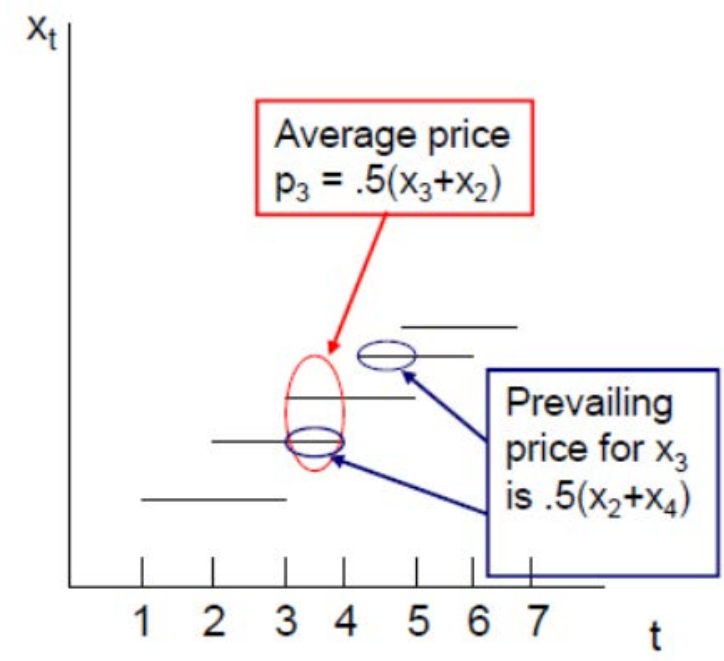

Figure 4. Illustration of a Canonical Staggered Contract Model 
This "contract" or "set" price $x_{t}$ is shown in the Figure 4. Note that it is fixed at the same level for two periods. Half the firms set their price each period in the canonical model. In the case where $\mathrm{x}$ is a wage rather than a price, it would also be set for two periods. There is no reason for either the price or the wage to be a formal contract or even an implicit contract; rather the price or wage set by the firm could apply to any particular good purchased or any worker of a certain type hired.

\subsection{Canonical Assumptions}

Two essential assumptions of staggered price setting are clear in the Figure 4. First, the set price lasts for more than an instant, or in this discrete time set up for more than one period. Second, the price setting is unsynchronized or overlapping. When you think about how a market might work in these circumstances, you realize two more important things not in the classic supply and demand framework. First, you realize that some firms’ prices will be outstanding when another firm is deciding on a price to set. So firms need to look back at the price decisions of other firms. Second, you realize that the firm's price will be around for a while, so the firm will have to think ahead and forecast the price decisions of other firms.

Figure 4 also illustrates two important concepts: the average price $\mathrm{p}_{\mathrm{t}}=\left(\mathrm{x}_{\mathrm{t}}+\mathrm{x}_{\mathrm{t}-1}\right)$ and the prevailing price. For period t, the prevailing price is the average of the price in effect in period t1 and the price expected to be in effect in period $t+1$, that is $.5\left(x_{t-1}+E_{t-1} x_{t+1}\right)$. This is what is relevant for the price decision of the firm in period $t$.

Given this set up, a decision rule for the firm setting the price $\mathrm{x}_{\mathrm{t}}$ at time $\mathrm{t}$ can be written down directly, as I originally did in Taylor (1979), as a function of the prevailing price (set by other firms in the market) and a measure of demand pressure in the market during the period the 
price will be in effect. The intuitive idea is simply that firms increase their price above the prevailing price if they see that demand conditions in the market are strong, and vice versa if demand conditions are weak. There can also be a random shock reflecting mistakes or other factors affecting the pricing decision. The result is shown in equation (1). As we will see later in this chapter, this equation can be derived explicitly from a specific profit maximization problem of a firm in monopolistic competition. ${ }^{5}$

The term $E_{t-1}$ represents the conditional expectations operator, the term $y_{t}$ is a measure of demand (which for simplicity I will take to be the percentage deviation of real output from potential output), and $\varepsilon_{t}$ is a serially uncorrelated, zero mean random shock.

$x_{t}=\frac{1}{2}\left(x_{t-1}+E_{t-1} x_{t+1}\right)+\frac{\gamma}{2}\left(E_{t-1} y_{t}+E_{t-1} y_{t+1}\right)+\varepsilon_{t}$

As I explain below, the “demand' variable on the right hand side of equation (1) can also be interpreted as marginal cost in the case of a price decision (Woodford (2003)) or marginal revenue product in the case of a wage decision (Erceg, Henderson and Levin (2000)) rather than the output gap.

\subsection{Two More Equations and a Dynamic Stochastic General Equilibrium Model}

To derive the implications of the staggered contracts assumption for aggregate dynamics and the persistence of shocks, we need to embed the staggered price setting equation into a

\footnotetext{
${ }^{5}$ Note that (ignoring the expectations operator) the first term on the right hand side of equation (1) can be written as $\frac{1}{2}\left(p_{t}+p_{t+1}\right)$ because this equals $\frac{1}{2}\left[\frac{1}{2}\left(x_{t}+x_{t-1}\right)+\frac{1}{2}\left(x_{t+1}+x_{t}\right)\right]$ and thus $x_{t}=$ $\frac{1}{2}\left(x_{t-1}+x_{t+1}\right)+\ldots$
} 
model of the economy. For this purpose, consider two additional simple equations: An aggregate demand equation based on a money demand function (which could be derived from a money-inthe-utility or cash-in-advance framework) and an equation describing a monetary policy rule in which the money supply is adjusted by the central bank in response to movements in the price level. The two equations are thus:

$\mathrm{y}_{\mathrm{t}}=\alpha\left(m_{t}-p_{t}\right)+v_{t}$

$m_{t}=g p_{t} \quad(\mathrm{~g}<1)$

which can be combined to get

$$
y_{t}=-\beta p_{t}+v_{t}
$$

where $\beta=\alpha(1-g)$ is the key policy parameter.

Here we define y to be the log of real output (de-trended) as in equation (1) and $\mathrm{m}$ to be the $\log$ of the money supply. In the case where $\alpha=1, v$ is simply the log of velocity, which can be a random variable with zero mean. The policy rule is effectively a price rule with a price level target of 0 for the log of the price level. Now if we insert the staggered contract equation (1) into the model we get the following difference equation with lags and leads 


$$
\begin{aligned}
& x_{t}=\frac{1}{2}\left(x_{t-1}+E_{t-1} x_{t+1}\right)+\frac{\gamma}{2}\left[-\beta\left(\frac{E_{t-1} x_{t}+x_{t-1}}{2}\right)-\beta\left(\frac{E_{t-1} x_{t+1}+E_{t-1} x_{t}}{2}\right)\right]+\varepsilon_{t} \\
& =\frac{1}{2}\left(x_{t-1}+E_{t-1} x_{t+1}\right)-\frac{\gamma \beta}{4}\left[E_{t-1} x_{t+1}+2 E_{t-1} x_{t}+x_{t-1}\right]+\varepsilon_{t}
\end{aligned}
$$

The solution is

$x_{t}=a x_{t-1}+\varepsilon_{t}$

where $a=c \pm \sqrt{c^{2}-1}$ and where c $=(1+\beta \gamma / 2) /(1-\beta \gamma / 2)$.

Clearly $c>1$, and we can chose stable root for uniqueness.

In terms of the aggregate price level, this implies that

$p_{t}=a p_{t-1}+.5\left(\varepsilon_{t}+\varepsilon_{t-1}\right)$

an ARMA (1,1) from which steady state variances can easily be found

$$
\begin{aligned}
& \sigma_{p}^{2}=.5 \sigma_{\varepsilon}^{2} /(1-a) \\
& \sigma_{y}^{2}=\beta^{2} \sigma_{p}^{2}
\end{aligned}
$$

Note that the three equation macro model consists of a staggered price setting equation (1), a policy transmission equation (2), and a policy rule (3). The model is a combination of sticky prices and rational expectations which is the hallmark of New Keynesian models, a term which distinguishes them from Old Keynesian models in which expectations are not rational and prices are either fixed or determined in a purely backward looking manner, unlike equation (1). To be sure, the term New Keynesian is used in different ways by different researchers and can be misleading. For example, in some usages the term refers only to models in which the monetary transmission equation is an IS curve-perhaps derived from a Euler equation-relating the 
policy interest rate to aggregate demand and the policy rule is an interest rate rule like the Taylor rule.

Observe that the persistence of the aggregate price level, which is determined by the parameter $a$ in equation (6), and aggregate output depends on the structure of the staggered pricing $\gamma$ but also on the policy rule $g$. In other words, persistence is a general equilibrium phenomenon depending on both the price setting mechanism and on policy. This idea that one needs a whole model rather than a single price-setting equation to assess the degree of aggregate persistence will come up again in this chapter.

Also note that in this simple model the money supply is stationary so the persistence is in the price level rather than the inflation rate. In a more realistic model the growth rate of the money rather than the money supply would be stationary.

\subsection{The Policy Problem and the Output and Price Stability Tradeoff Curve}

An objective function or loss function for monetary policy in this model can be written in terms the variances of $y_{t}$ and $p_{t}$. For example, if the loss function is $\lambda \operatorname{var}\left(p_{t}\right)+(1-\lambda) \operatorname{var}\left(y_{t}\right)$, then the monetary policy problem is to choose a value of $g$ (which determines $\beta$ and thus $a$ ) to minimize this loss function. As the policy parameter is changed, the variances of $\mathrm{p}$ and y move in opposite directions tracing out a variance tradeoff curve. The lower panel of Figure 5 illustrates this variance trade off curve. Inefficient monetary policies would be outside the curve. Points inside the curve are not feasible. Performance could be improved by moving toward the curve. 

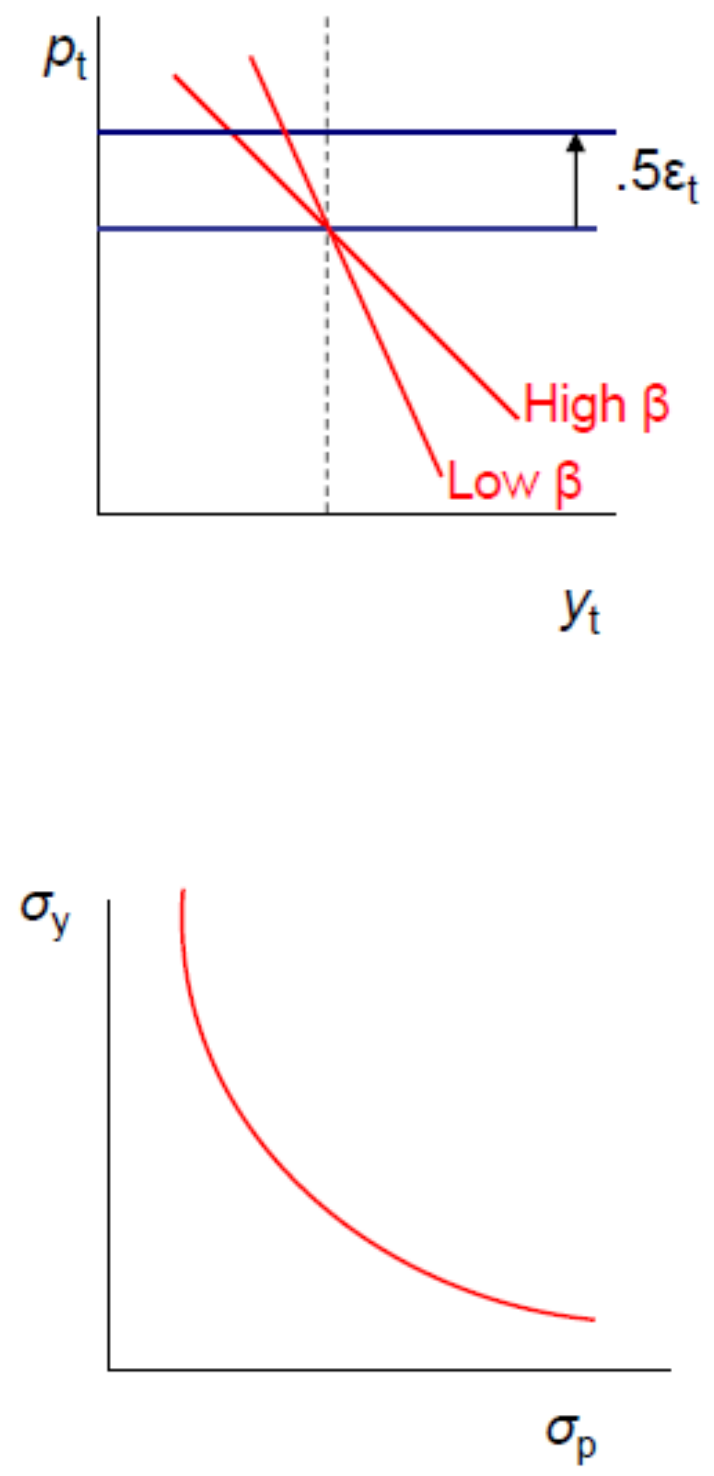

Figure 5. Output and Price Stability Tradeoff Curve with Graphical Explanation

The upper panel of Figure 5 is an aggregate demand-aggregate supply diagram which illustrates how the choice of $g$, and thus $\beta$, affects the variance of $p$ and $y$. Suppose that there is a shock $\varepsilon$ to the price setting equation. Then a steep aggregate demand curve (a monetary policy choice) makes for smaller fluctuations in y, but also means that a given shock to the price level takes a long time to diminish and thus a larger average fluctuation in $\mathrm{p}$. 


\subsection{Key Implications}

A number of important implications of staggered contracts can be illustrated with the canonical model, and they also hold in more complex models. I summarize these implications here.

(1) The theory centers around a simple equation that can be used and tested. I list this result first because if the theory had not yielded an equation, such as equation (1), it would have been difficult to achieve the progress I report in this chapter-including the empirical validation exercises reported in the previous section and the theoretical derivation of the equation using a profit maximization with monopolistic competition framework reported below. A key variable in this equation is the prevailing price (or wage) set by other firms. The prevailing price itself is an average of prices set in the past and prices to be set in the future. In this case the coefficients on past and the future are equal.

(2) Expectations of future prices matter for pricing decisions today. This is shown clearly in equation (1). The reason is that with the current price decision expected to last into the future, some prices set in the future will be relevant for today's decision. This is an important result because expectations of future inflation now come into play in the theory of inflation. It gives a rationale for central bank credibility and for having an inflation target.

(3) There is inertia or persistence in the price setting process; past prices matter because they are relevant for present price decisions. The coefficients on past prices can be calculated from the staggered price setting assumptions. This implication can be most readily seen in equation (5). The contract price is serially correlated. It is persistent and it can be described by an autoregressive process. 
(4) The inertia or persistence is longer than the length of the period during which prices are fixed. Price shocks take a long time to run through the market because last period's price decisions depend on price decisions in the period before that and so on into the distant past. I originally called this phenomenon the "contract multiplier" because it was analogous to the Keynesian multiplier where a shock to consumption builds up and persists over time as it works its way through the economy from income to consumption to income back again, and so on. This is most easily seen in equation (5) or the ARMA model in equation (6). The first order autoregression implies an infinite auto-correlation function or an infinite impulse response function. The larger the autoregressive coefficient (that is, $a$ ) is, the larger will be the contract multiplier. This is one of the most important properties of the staggered contract model because it means that very small rigidities at the micro level can generate large persistent effects for the aggregates. Klenow and Malin (2011) explain it well: "Real effects of nominal shocks...last three to five times longer than individual prices. Nominal stickiness appears insufficient to explain why aggregate prices respond so sluggishly to monetary policy shocks. For this reason, nominal price stickiness is usually combined with a 'contract multiplier' (in Taylor's 1980 phrase).”

(5) The degree of inertia or persistence depends on monetary policy. That is: the autoregressive coefficient $a$ depends on the policy parameter $g$. The more accommodative the central bank is to price level movements (higher $g$ ), the more inertia there will be (higher $a$ ).

(6) The theory implies a tradeoff curve between price stability and output stability. This tradeoff curve has provided a framework for discussion and debate about the role of policy in economic performance for many years. Originally put forth in Taylor (1979a) it is referred to as the Taylor curve in various contexts (King (1999), Bernanke (2004), Friedman (2010)). 
Bernanke (2004) used such a tradeoff curve to explain the role of monetary policy during the Great Moderation. His explanation was that monetary policy improved and this brought performance from the upper right hand part of the diagram down and to the left closer to or even on the curve.

King (1999) made similar arguments. However, when the Great Recession and the slow recovery moved the performance in the direction of higher output instability—the end of the Great Moderation—King (2012) argued that the tradeoff curve itself shifted. As he put it, “A failure to take financial instability into account creates an unduly optimistic view of where the Taylor frontier lies.... Relative to a Taylor frontier that reflects only aggregate demand and cost shocks, the addition of financial instability shocks generates what I call the Minsky-Taylor frontier.”

Note that the tradeoff implies that there is no "divine coincidence" as put forth by Blanchard and Gali (2007). Divine coincidence means that there is no such tradeoff between output stability and price stability, completely contrary to the existence of the tradeoff in Figure 2. Divine coincidence could occur if there were no shocks to the contract price or wage equation, but that is not the basic assumption of the staggered contract model. Broadbent (2014) suggested that the Great Moderation was due to the sudden appearance of divine coincidence, rather than to an improved monetary policy performance that brought the economy closer to the tradeoff curve as Bernanke (2004) and others argued.

(7) The costs of reducing inflation are less than in a backward-looking expectations augmented Phillips curve. In the staggered contract model disinflation could be less costly if expectations of inflation were lower because of the forward-looking component of the model, as explained in Taylor (1982) though with reservations from others. The disinflation costs would 
not normally be zero as in the case of rational expectations models with perfectly flexible prices, but they would be surprisingly small. This prediction proved accurate when people later examined the disinflation of the early 1980s.

\section{Generalizations and Extensions}

These results remain robust to variations in the model. An important variant is to allow for a greater variety of time intervals during which prices are fixed. Of course one could have longer contracts as in Taylor (1980) where contracts were of a general length N. However, a model with all price and wage setting being the same length is a simplifying assumption, not something that could be used in empirical work. The high degree of heterogeneity described in the microeconomic research reviewed above makes this very clear. Not all contracts are $\mathrm{N}$ periods in length; some are shorter and some are longer. Indeed, there is a whole distribution of contracts and this is what I assumed in early empirical work with these models. For example, a generalized distribution of price-wage setting intervals was used by Taylor (1979c) in an estimated model of the United States.

Equation (1) was thus modified as follows.

$$
\begin{aligned}
& x_{t}=\sum_{i=0}^{N-1} \theta_{i t} E_{t}\left(p_{t+i}+\gamma y_{t+i}+\varepsilon_{t+i}\right) \\
& p_{t}=\sum_{i=0}^{N-1} \delta_{i t} x_{t-i}
\end{aligned}
$$

The weights $\theta_{i t}$ and $\delta_{i t}$ were estimated using aggregate wage data in the United States. The estimation of the lag and lead coefficients was only mildly restricted, allowing for a peak somewhere between 1 quarter and 8 quarters. The estimated distribution from Taylor (1979c, Table 4) is plotted in Figure 6 below. It has a peak at 3 quarters with 24 percent of workers; only 
7 percent had one quarter contracts and only 2 percent had 8 quarter contracts. The interpretation was that the economy consisted of a whole variety of price and wage setting practices.

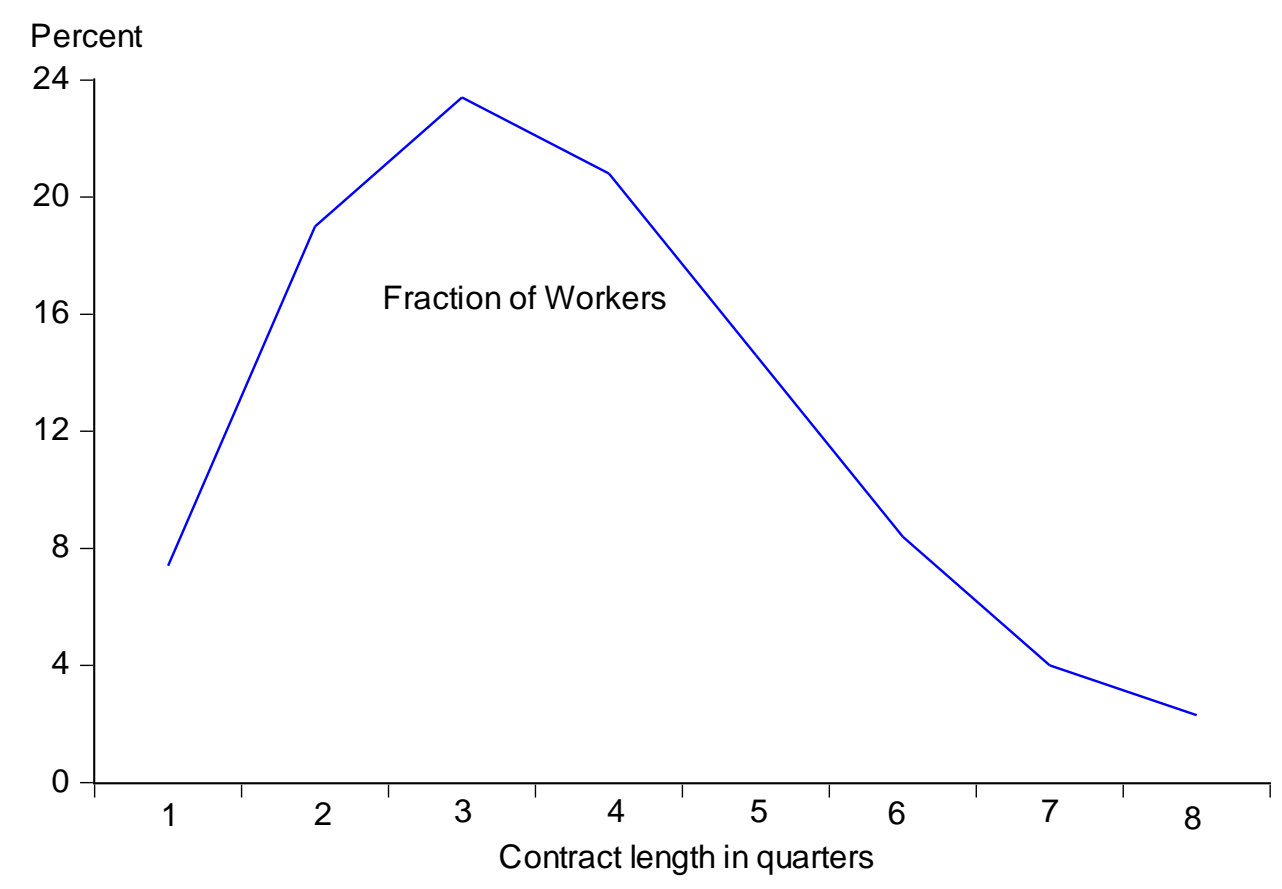

Figure 6: The Estimated Distribution of Workers by Contract Length

Observing this empirical distribution of wage setting intervals in Taylor (1979c) gave my then colleague at Columbia University, Guillermo Calvo, the idea of an important simplification. Why not assume a geometric distribution, which would be considerably simpler? Moreover, such a distribution could be interpreted as being generated probabilistically rather than deterministically if each wage contract expired randomly rather than deterministically. The resulting model came to be called the Calvo model and the random selection process came to be called the Calvo fairy. The equation for the price change is a specific version of equations (7) and (8) and can be written as follows: 


$$
\begin{aligned}
& x_{t}=(1-\beta \omega) \sum_{i=0}^{\infty}(\beta \omega)^{i} E_{t}\left(p_{t+i}+\gamma y_{t+i}+\varepsilon_{t}\right) \\
& p_{t}=(1-\omega) \sum_{i=0}^{\infty} \omega^{i} x_{t-i}
\end{aligned}
$$

After some manipulation, these two equations can be rewritten as

$x_{t}=\beta \omega E_{t} x_{t+1}+(1-\beta \omega)\left(p_{t}+y_{t}+\varepsilon_{t}\right)$

$p_{t}=\omega p_{t-i}+(1-\omega) x_{t}$

Once a model for $y$ and the impact of monetary policy is added, you have a well - defined rational expectations model as before.

The two equations can also be re - written in an interesting form :

$\pi_{t}=\beta E_{t} \pi_{\mathrm{t}+1}+\delta \gamma y_{t}+\delta \varepsilon_{t}$

where

$\delta=\left[\frac{(1-\omega)(1-\beta \omega)}{\omega}\right]$

which is very simple and reminiscent of an old expectations augmented Phillips curve except that the expected inflation rate next period rather than this period is on the right hand side. Calvo's modifiations helped the staggered contract model grow in use and popularity. Indeed, this form of the staggered price setting model in equation (1) came to be popularly known as the New Keynesian Phillips Curve.

\section{Derivation of Staggered Price Setting When Firms Have Market Power}

Another important development regarding the staggered contract model was its derivation from an optimization problem in which firms face a downward sloping demand curve and decide on an optimal price subject to the staggered contract restriction that they cannot change prices every period. The idea of using market power to derive a price setting equation goes back to 
Svensson (1986), Blanchard and Kiyotaki (1987), Akerlof and Yellen (1991) as I reviewed in Taylor (1999). As described below, Chari, Kehoe and McGrattan (2000) used the approach as part of a critique of staggered price setting. For expository purposes here, I focus on a simple derivation used in Taylor (2000) in which firms maximize profits taking the downward sloping demand curve for their products as given.

Consider a firm selling a product that is differentiated from the other goods. The demand curve facing each firm is linear in the difference between the firm's own price for its product and the average price for the other differentiated products. Such a linear demand curve can be derived from models of consumer utility maximization. Suppose that this linear demand curve is written as

$$
y_{t}=\varepsilon_{t}-\beta\left(x_{t}-p_{t}\right)
$$

where $y_{t}$ is production, $x_{t}$ is the price of the good, and $p_{t}$ is the average price of other (differentiated) goods. The term $\varepsilon_{t}$ is a random shift to demand.

Suppose that the firm sets its price to last for two periods, and that it sets its price every second period. Other firms set their price for two periods, but at different points in time. These timing assumptions correspond to the canonical model in Figure 1, and the average price is just as in the canonical model $p_{t}=.5\left(x_{t}+x_{t-1}\right)$.

Let $c_{t}$ be the marginal cost of producing the good. Under these assumptions, the firm's expected profit for the two periods to which the price set in period t applies is given by

$$
\sum_{i=0}^{1} E_{t}\left(x_{t} y_{t+i}-c_{t+i} y_{t+i}\right)
$$

where $x_{t}$ applies in period $\mathrm{t}$ and period $\mathrm{t}+1$. (I have assumed for simplicity that the discount factor is 1). Firms maximize profits taking marginal cost and average price at other firms as given. 
Differentiating with respect to $\mathrm{x}_{\mathrm{t}}$ results in the solution for the optimal price

$$
x_{t}=.25 \sum_{i=0}^{1}\left(E_{t} c_{t+i}+E_{t} p_{t+i}+E_{t} \varepsilon_{t+i} / \beta\right)
$$

which is analogous to the canonical staggered contracting equation in equation (1) (see also Footnote 1). Note however that it is marginal cost that enters the equation rather than the output gap, an issue I will come back to later in this chapter. Note that the coefficient of 0.25 implies that an increase in the price and marginal cost at other firms results in the same increase in the firm's price.

\subsection{Pass-Through Implications}

Though the derivation generates the same basic staggered price setting equation as assumed in the canonical model, it reveals another important implication of the theory —an “eighth” implication: a more price-stability-focused monetary policy—say due to inflation targeting-implies a smaller pass-through of price shocks (commodities or exchange rates) to inflation. That this implication might be borne out by reality was noted in Taylor (2000), but has now been documented in empirical studies in many countries. The reason originally given for the empirically observed decline in pass-through was that there was a reduction in the "pricing power" of firms. But another view is that the decline in pass-through is due to the low inflation rate achieved by a change in monetary policy.

To see this note that, according to equation (14), the amount by which a firm matches an increase in marginal cost with an increase in its own price depends on how permanent that marginal cost increase is. Similarly, the extent to which an increase in the price at other firms will lead to an increase in the firm's own price will depend on how permanent that increase in 
other firms' prices is expected to be. However, in neither case does the extent of this passthrough depend on the slope of the demand curve.

To see how the pass-through of an increase in marginal costs depends on the persistence of the increase, suppose that marginal cost follows a simple first order auto-regression:

$$
c_{t}=\rho c_{t-1}+u_{t}
$$

In this case the pass-through coefficient will be proportional to $(1+\rho)$. Thus, less persistent marginal costs (lower $\rho$ ) reduce the pass-through coefficient, even though it might seem like a reduction in pricing power. The general point is that if an increase in costs is expected to last, then the increase will be passed-through to a greater extent. A more stable price level will reduce the persistence.

For firms that import inputs to production, marginal cost will depend on the exchange rate. Currency depreciation will raise the cost of the imports in domestic currency units. According to this model, if the depreciation is viewed as temporary, the firm will pass through less of the depreciation in the form of a higher price. Hence, less persistent exchange rate fluctuations will lead to smaller exchange rate pass-through coefficients. A more stable price level will lead to less persistent changes in exchange rates.

\subsection{Marginal Cost versus the Output Gap}

Note that equation (14) has marginal cost driving price movements rather than output as assumed in equation (1). To make the connection between equation (14) and equation (1) (again keeping footnote 1 in mind) we need to think of marginal cost as moving proportionately to the

movements in the output gap. Gali and Gertler (1999) or Gali, Gertler and Lopez-Salido (2005) argue that there are plenty of reasons why marginal cost and the output gap might diverge from 
time to time. So they look at a version of equation (11) in which marginal costs appear rather than the gap (they use the geometric distribution assumption of Calvo rather than the canonical form used here). Though the empirical accuracy of this equation was questioned by Mankiw (2001), the paper by Gali et al. (2005) finds that marginal cost is significant and quantitatively important. However, they introduce a modification in that model. They assume that a fraction of firms changes price with a backward looking "rule of thumb” which simply depends on past inflation. They thereby create a hybrid model with the lagged inflation rate on the right hand side. The modification is ad hoc_-especially compared with the theory that goes into deriving the staggered price setting equation.

Another issue noted by Nekarda and Ramey (2013) is that the markup of price over marginal cost needs to move in a countercyclical way if the equation is to explain empirically the effects of a change in demand on prices. They report, however, that markups are either "procyclical or acyclical conditional on demand shocks" and thereby conclude that the "New Keynesian explanation for the effects of government spending or monetary policy is not supported by the behavior of the markup.”

Fuhrer (2006) raised further questions about the New Keynesian Phillips curve. He shows that in the New Keynesian Phillips curve inflation it is persistence of the shock rather than the equation itself that is the dominant source of persistence.

\subsection{Debate Over the Contract Multiplier}

Yet another issue is whether the contract multiplier is capable of explaining the persistence of prices or output. In the canonical model, including its derivation from profit maximization, the contract multiplier can be represented by the size of the autoregressive 
coefficient in the aggregate price equation. Chari Kehoe and McGrattan (2000) argued that for the parameters derived from the maximization problem, this coefficient is not large enough to be capable of explaining persistence, at least for contract lengths of one quarter in length and their particular measure of aggregate persistence. Woodford (2003, pp. 193-194) argues that their conclusion "depends on an exaggeration of the size of the contract multiplier that would be needed and an underestimate of the empirically plausible degree of strategic complementarities.” He also argues that Chari, Kehoe and McGrattan (2000) set up too high a persistence hurdle for the contract multiplier, in effect asking it to explain persistence that is more reasonably due to other serially correlated variables in the model.

Christiano Eichenbaum and Evans (2005) argue that assuming that the representative length of contracts is only one quarter is too small. If one uses somewhat longer contracts, say close to the survey summarized by Klenow and Malin (2011), the contract multiplier seems to work fine. Christiano Eichenbaum and Evans (2005) also question the persistence measure used by Chari, Kehoe and McGrattan (2000).

\section{Price and Wage Setting Together}

Much of this review has focused thus far on staggered price setting, but the original work on staggered contracts was about wages, where the time between wage changes is quite a bit longer according to the recent microeconomic empirical research summarized in this chapter. In Taylor (1980) the staggering of wages was the key part of the model, and this created a persistence of prices through a simple fixed markup of prices over wages. The micro finding summarized by Klenow and Malin (2011) that “price changes are linked to wage changes” supports this idea. Of course the markup need not be literally fixed. In the empirical multi- 
country model in Taylor (1993), the staggered wage contracting equations were estimated for seven countries and markups of prices over wages were influenced by the price of imports.

Erceg, Henderson, and Levin (2000) brought the focus back on wages, but with an important innovation. Rather than simply marking up prices over wages, they built a model which combined staggered price and wage setting, and, moreover, they derived both equations from profit or utility maximization considerations as in Section 5 above. Their work in turn helped enable the development of more empirically accurate estimated policy models, such as those due to Christiano, Eichenbaum and Evans (2005), Smets and Wouters (2003), and many others that have become part of Volker Wieland's model data base described in Wieland et al. (2012).

The model of Christiano, Eichenbaum and Evans (2005) assumes staggered contracts for prices and wages with Calvo contracts. It was the first medium-sized, estimated example of a New-Keynesian model explicitly derived from optimizing behavior of representative households and firms. It stimulated the development of similar optimization-based models for many other countries, and has been dubbed the second generation new Keynesian model along with Smets and Wouters (2003) by Wieland et al (2016). Smets and Wouters $(2003,2007)$ also showed how to use Bayesian techniques (Geweke (1999) and Schorfheide (2000)) in estimating such models.

An important question for research is how the overall properties of the models changed as a result of the innovations. The eight implications mentioned above still hold in my view but the quantitative sizes of the impacts are important to pin down. Taylor and Wieland (2012) investigated this question using a new database of models designed for this purpose. They considered a first generation model—-the Taylor (1993) multicountry model mentioned in the previous section with staggered contracts. And they compared this with two second generation 
models - the Christiano, Eichenbaum, Evans (2005) model and the Smets and Wouters (2007) model. Although the models differ in structure and sample period for estimation, the impacts of unanticipated changes in the federal funds rate are surprisingly similar. In the chapter prepared for this Handbook Wieland, Afanasyeva, Kuete, and Yoo (2016) shows that these surprising results continue to hold if one adds a third generation of models in which credit market frictions play a role in the monetary transmission mechanism.

There is a difference between the models in the evaluation of monetary policy rules, however. Model-specific policy rules that include the lagged interest rate, inflation and current and lagged output gaps are not robust. Policy rules without interest-rate smoothing or with GDPgrowth replacing the GDP gap are more robust, but performance in each model is worse with the more robust rule.

\section{Persistence of Inflation and Indexing}

Prior to the work of Chari, Kehoe and McGrattan (2000), Fuhrer and Moore (1995) raised questions about the ability of the staggered contract model to explain the persistence of inflation rather than the persistence of the price level. They proposed a modification of the model to deal with this problem. As I reviewed in Taylor (1999), they transformed the model from price levels into the inflation rate, noting that it was relative wages rather than absolute wages that would go into the staggering equations. But the rational for focusing on relative wages was weak and questions about this issue continued into the 2000s.

In recent years many have argued that the degree of persistence implied by the basic staggered contract model is just fine and consistent with the data. Guerrieri (2006), for example, argued that when the staggered contract model is viewed within the context of a fully-specified 
macro model, inflation persistence and its changes over time could be explained with the regular staggered contract setup. I illustrated this idea with the canonical model I presented earlier in this chapter in which persistence is a general equilibrium phenomenon.

Guerrieri (2006) used a vector auto-regression with inflation, the interest rate, and output to represent the facts that a staggered contract model should explain. He found that the basic staggered contract model did as well as the Fuhrer-Moore (1995) relative contract model in generating the actual inflation persistence in the United States through the 1990s. The impulse response functions reported in his paper show the degree to which both specifications can explain the inflation process. The staggered contract models are well within the $95 \%$ confidence bands with the exception of the cross impulse response functions for output and inflation.

Nevertheless, both Christiano, Eichenbaun and Evans (2005) and Smets and Wouters (2003) felt the need to modify the staggered price and wage setting equations in order to get the proper persistence and better match the other cross correlations. They assumed backwardlooking indexation in those periods when prices and wages were not allowed to adjust. The Christiano, Eichenbaum, Evans (2005) model assumes wages and prices are indexed to last period's inflation rate during periods between changes. The Smets-Wouters model assumes firms index to a weighted average of lagged and steady-state inflation.

None of these modifications are part of the optimization process; they are akin to simply assuming that wage and price inflation is autoregressive in an ad hoc way rather than deriving the equations: Why bother with a micro-founded staggered wage and price setting model if you are just going to add ad hoc lag structure anyway?

In fact, it appears that the persistence problem is not due the staggered contract model but rather to the special Calvo form it takes in these models. 


\section{Taylor Contracts and Calvo Contracts}

Much has been written comparing "Calvo contracts" described in Section 5 of this chapter and "Taylor contracts" which appear in the canonical model in the case of two period contracts in Section 4. Walsh (2010, p.243)) notes some of the similarities between equations (his equation (6.17) and equation (6.36)) derived from the two staggered price setting models, but others, including Kiley (2002), have emphasized the differences. For example, the persistence of inflation and output appears to be greater in the Calvo contracts for the same average frequency of price change.

There is no question that there is a much longer tail in the Calvo model than for any fixed length contract, but Dixon and Kara (2006) argue that Kiley’s comparison is flawed because it compares "the average age of Calvo contracts with the completed length of Taylor contracts." When Dixon and Kara (2006) compare average age Taylor contracts with the same average age Calvo contracts, the differences become much smaller. They also show that output can be more auto-correlated with Taylor contracts with “age-equivalent” Calvo contracts.

Carvalho and Schwartzman (2015) examine the differences in monetary neutrality in the two types of models by distinguishing between Taylor contracts and Calvo contracts in terms of their “selection effect.' At any point in time after a monetary shock, some firms have a lot of old prices and some do not. "Positive” selection is defined as a situation where old prices are overrepresented among adjusting prices. In Taylor contracts, selection favors old prices; in Calvo contracts there is no selection, since prices change completely at random. This selection effect characterizes pricing frictions. Taylor contracts imply smaller non-neutralities of money on output than Calvo contracts because of differences in selection 
Of course there is no reason to focus—as these studies do—on the special case of "Taylor contracts" in which all contracts are the same length as in the simple exposition in the canonical model. The microeconomic evidence and casual observation suggest rather that there is a great deal of heterogeneity of lengths of both wage contracts and price contracts. In a series of papers Dixon and Kara (2005, 2006, 2011) and Kara (2010) develop models which are built on this heterogeneity. They call these models a Generalized Taylor Economy (GTE) in which many sectors have staggered contracts with different lengths. When two such economies have the same average length contracts, monetary shocks are more persistent with longer contracts. They also show that when two GTE’s have the same distribution of completed contract lengths, the economies behave in a similar manner. See also Huw Dixon’s comprehensive web page http://huwdixon.org/GTE.html on the Generalized Taylor Economy and his paper with Herve Le Bihan (Dixon and Lle Bihan (2012),

In a more recent paper Kara (2015) shows that adding the heterogeneity in price stickiness to the Smets and Wouters model deals with criticisms of the staggered contract model including the Chari, Kehoe and Mcgrattan (2009) criticism that the Smets and Wouters model relies on unrealistically large price mark-up shocks to explain the data on inflation and the Bils, Klenow and Malin (2012) criticism that reset price inflation in the model is more volatile than the data show. Kara (2015) shows that adding heterogeneity in the length of contracts to correspond with the data implies smaller price mark-up shocks and less volatile reset price inflation.

In yet another study comparing the two approaches, Knell (2010) examined survey data on wage-setting in 15 European countries from the Wage Dynamics Network (WDN) discussed in Section 2 of this chapter. It is informative to quote from his paper: "There are at least four 
dimensions along which the data contradict the basic model with Calvo contracts. First, the majority of wage agreements seems to follow a predetermined pattern with given contract lengths. Second, while for most contracts this predetermined length is one year (on average 60\% in the WDN survey) there exists also some heterogeneity in this context and a nonnegligible share of contracts has longer (26\%) or shorter (12\%) durations. Third, 54\% of the firms asked in the WDN survey have indicated that they carry out wage changes in a particular month (most of them-30\% — in January). Fourth, 15\% of all firms report to use automatic indexation of wages to the rate of inflation. In order to be able to take these real-world characteristics of wage-setting into account one has to move beyond the convenient but restrictive framework of Calvo wage contracts.” Knell then presents a model along the lines of Taylor (1980) that allows one to incorporate all of these institutional details.

Musy (2006) and Ben Aissa and Musy (2010) have investigated the differences between the Calvo contracts model and the Taylor contracts model and others. Their analysis shows that criticism of a lack of persistence or an under estimate of the costs of disinflation are due to very special features of the Calvo assumptions. Recall that the "Calvo fairy' is a mechanism for randomly choosing a price to change each period. That probability is a constant, so in effect Calvo contracts are neither time dependent or state dependent. The work of Musy and Ben Aissa shows that a change in money growth will not be accomplished in a costless manner in the Taylor model even though it is in the Calvo model, and that persistence is greater.

\section{State Dependent Models and Time-Dependent Models}

Another development has been to relax the simplifying assumption that prices are set for an exogenous interval and allow the firm's price decision to depend on the state of the market, 
which gave rise to name "state dependent" pricing models and created the need to give the original canonical model a new name, “time dependent.” (See Dotsey, King, and Wolman (1999), Golosov and Lucas (2007), and Gertler and Leahy ( 2008)). There are some benefits from these improvements as Klenow and Kryvtsov (2008) have shown using new microeconomic data. Many of the key policy implication mentioned above hold, but the impact of monetary shocks can be smaller.

Alvarez and Lippi (2014) consider a state-dependent model with multiproduct firms, which is otherwise similar to the state dependent model of Golosov and Lucas (2007). They find that as they alter the model from one product firm to a multiproduct firm, the impact of monetary shocks becomes larger and more persistent. For a large number of products they show that the economy works as in the staggered contract model: it has the same aggregation and impulse response to a monetary shock. In this sense, the menu cost models with multi-product firms gives another basis to the staggered contract model.

Woodford (2003, p. 142) questions whether the state dependent models are really any better than the staggered contract models. Not only are they more complex, he argues, but they may be less realistic and have inferior micro-foundations. The idea that firms are constantly evaluating the price misses the point that firms set their prices for a while to reduce "the costs associated with information collection and decision making.” Kehoe and Midrigan (2010) have developed a model in which formal considerations of such management costs do indeed increase the impact and persistence of shocks.

Bonomo and Carvalho (2004) develop a model of the micro-foundations of the timedependent model in which the length of time that prices are fixed is endogenous. In their model firms face a joint lump-sum adjustment and information cost rather than a pure adjustment cost, 
and for this reason optimal pricing is not state-dependent. Their model is thus a way to deal with the observation that contract length depends on the rate of inflation and the variability of inflation and other shocks. They not only show that time-dependent models are optimal, they derive the optimal contract length.

They examine the effect of different policies such as a disinflation and examine the difference with invariant time dependent arrangements. In a subsequent paper, Bonomo and Carvalho (2010) estimate the macroeconomic costs of a lack of credibility of monetary policy. They find that the costs are greater for the endogenous time-dependence model than for an exogenous time-dependent model

\section{Wage-Employment Bargaining and Staggered Contracts}

In recent years there has been an increased interest in explaining fluctuations in unemployment as well as output. As explained by Hall (2005), the standard wage-employment bargaining model needs to assume some form of sticky wages if it is to be consistent with the data, and for this reason the idea of nominal rigidities is common to this research. It is not surprising therefore that many of the models built to examine this question have combined staggered contracts with a formal treatment of the wage-employment bargaining. Ravenna and Walsh (2008), Gertler, Sala and Trigari (2008), and Christiano, Eichenbaum and Trabandt (2013) are examples.

There are some byproducts of this research too. The Christiano, Eichenbaum and Trabandt (2013) model is able to drop the arbitrary indexing assumption in Christiano, Eichenbaum and Evans and still get the requisite persistence. This works because when a monetary shock increases the demand for output which sticky price firms produce, the firms also 
purchase more wholesale goods. With this model, the authors argue that "alternating offer bargaining mutes the increase in real wages, thus allowing for a large rise in employment, a substantial decline in unemployment, and a small rise in inflation.”

\section{Staggered Contracts versus Inattention Models}

Mankiw and Ries (2001) have argued that the staggered wage and price setting should be replaced by a model with inattention. They argue in favor of sticky information rather than sticky prices, mainly because such a model would solve the persistence problem alluded to above.

Recall that the concern is that there may be too little persistence of inflation following monetary shocks in staggered price setting models. Though some would argue that the persistence is fine, the lack of persistence may be more related to the specific form of the Calvo model rather than to the staggered contracts per se.

Why do Mankiw and Ries (2001) find that there is more persistence with inattention than with staggered contracts? Upon examination of their model, it appears that in the sticky information model, the price could be set to increase during the period where it is fixed in the regular model. For example in a staggered contract model of four periods the price would be $1.015,1.015,1.015,1.015$ while in the sticky information it could be set as 1.0, 1.01, 1.02, 1.03 and not change from that path. In effect, some inflation persistence is built in. Figure 7 illustrates this and can be compared with Figure 4. 


\section{$x_{t}$ "contract" price \\ or wage (case of "sticky information")}

Figure 7. Price setting with sticky information ( for comparison with Figure 4)

If prices or wages are set in this way, it is clear that there will be more persistence of inflation. It is very rare, however, for prices or wages to be set in this manner except in multiyear union contracts as explained in Taylor (1983) and Avouyi-Dovi (2013).

\section{Critical Assessment and Outlook}

From its origins nearly four decades ago to its applications today the staggered wage and price setting model continues to be a focus of attention in empirical and theoretical research in macroeconomics, especially in monetary business cycle models and monetary models used for policy analysis. In recent years "Big Data” style research projects have radically expanded our knowledge of the microeconomics of wage and price setting behavior from a few salient facts 
about magazine prices or personal salary experiences into complex data sets with thousands or millions of observations. These data sets require new methods of analysis, but they also permit researchers to test and discriminate much more thoroughly between one type of model and another. Criticisms - whether about inadequate micro-foundations, inability to explain certain facts, or questionable policy implications-have led to constructive improvements, clarifications, variations, new research lines, and, in some cases, less than fully satisfactory fixes.

In assessing the outlook for future research and applications of these models, one cannot help but be struck by a certain tension in current research. The large scale surveys and empirical research show a great deal of heterogeneity in wage and price setting behavior, yet most models still employ simplified models clearly at odds with this heterogeneity. Yes, there is evidence that prices are set at a fixed level for six months or more, especially if sales and reference prices are accounted for properly. Yes, there is evidence that wages are set a fixed level for longer periods and that there is a peak in the estimated hazard function at one year that precludes certain simplifications such as the Calvo model. Yes, there is evidence that both wage and price decisions are staggered or unsynchronized over time, and that this staggering creates a contract multiplier which converts short spells of rigidity at the micro level into longer persistence at the macro level. Yes, there is more evidence of time-dependence than state-dependence. But in each of these dimensions—-length, degree of staggering, shape of the hazard function, degree of statedependence - there is a great deal of heterogeneity across countries, types of product, types of employment, and types of industry structure.

This heterogeneity is not simply a nuisance; it has major implications for aggregate dynamics, and it has been offered as a response to criticism of staggered wage and price setting models. Often that criticism applies to a particular simple staggered contract model that does not 
capture either the regularities mentioned above or the heterogeneity, and that criticism disappears when heterogeneity is taken into account as Kara (2010) and Knell (2010) have emphasized. Rather than "jury-rig" simple staggered contract models with ad hoc add-ons, such as indexing in the models by Christiano Eichenbaum and Evans (2005) or Smets and Wouter (2003), this research suggests that building the heterogeneity into the model would both better fit the micro data and provide a straight forward explanation of macro persistence.

In other words, future research would likely yield large benefits if it moved on from "representative" staggered wage and price setting models to "heterogeneous" staggered wage and price setting models. The suggestion is similar to the idea of moving from "representative agent models" to "heterogeneous agent models," though the gains from such a move could be much greater.

The challenge is that building in this heterogeneity would complicate existing macro models which are already quite complicated, as I found when I began to build in such heterogeneity in my early research (Taylor 1979c) including in a multi-country model (Taylor (1993) with different degrees of staggered wage setting in different countries. Indeed, their complexity is the main object of criticism of the existing models as expressed by Chari, Kehoe and McGrattan (2009) and others.

At the least future research could go beyond continued comparisons of simplest text-book style models—-such as the random-length-contract Calvo model and the N-period-length-contract Taylor model—and look at heterogeneous or generalized models with a mix of contract types. But more fundamentally the challenge for future work is to find a way that takes account of the rich variety of wage and price setting procedures in a way that is tractable and understandable for 
policy analysis. Indeed, that has been the challenge for all areas of macroeconomic research from the very beginning. 


\section{References}

Akerlof, G.A., and J.L. Yellen (1991), "How large are the losses from rules of thumb behavior in models of the business cycle", in: W. Brainard, W. Nordhaus and H. Watts, eds., Money, Macroeconomics, and Economic Policy: Essays in Honor of James Tobin. MIT Press, Cambridge, MA.

Alvarez, Fernando and Francesco Lippi (2014), “Price Setting With Menu Cost for Multiproduct Firms,” Econometrica, Volume 82 (1), pp. 89-135.

Avouyi-Dovi, Sanvi, Denis Fouge`re, and Erwan Gautier, 2013. Wage rigidity, collective bargaining and the minimum wage: evidence from French agreement data, Review of Economics and Statistics, 95 (4), 1337-1351.

Backus, D. (1984), "Exchange rate dynamics in a model with staggered wage contracts", Discussion Paper No. 561 (Queen's University).

Barattieri, Alessandro, Susanto Basu, and Peter Gottschalk (2014), "Some Evidence on the Importance of Sticky Wages," American Economic Journal: Macroeconomics, 6 (1): 70101.

Ben Aissa, Mohamed Safouane and Olivier Musy (2010), The dynamic properties of alternative assumptions on price adjustment in New Keynesian models. Bull. Econ. Res. 63 (4), 353-384.

Benabou, R ., and C. Bismut (1987), "Wage bargaining and staggered contracts: theory and estimation", Discussion Paper No. 8810 (CEPREMAP, Paris, France).

Bernanke, Ben S. (2004), “The Great Moderation,” Eastern Economic Association, Washington, DC. 
Bils, Mark and Peter J. Klenow (2004), "Some Evidence on the Importance of Sticky Prices," Journal of Political Economy, 2004, 112 (5), 947-985.

Bils, Mark, Peter J. Klenow, and Benjamin A. Malin (2012), “Reset Price Inflation and the Impact of Monetary Policy Shocks,” American Economic Review, 102 (6): 2798-2825.

Blanchard, Olivier and Jordi Gali (2007), “Real Wage Rigidities and the New Keynesian Model," Journal of Money, Credit and Banking, Supplement to Vol. 39 (Suppl. 1), 3564.

Blanchard, O.J., and N. Kiyotaki (1987), "Monopolistic competition and the effects of aggregate demand", American Economic Review 77, 647-666.

Blinder, A.S., E.D. Canetti, D.E. Lebow and J.B. Rudd (1998), Asking About Prices: A New Approach to Understanding Price Stickiness (Russell Sage Foundation, New York, NY).

Bonomo, Marco and Carlos Carvalho (2004), “Endogenous Time-Dependent Rules and Inflation Inertia,” Journal of Money, Credit and Banking, 36 (6), 1015-1041.

Bonomo, Marco and Carlos Carvalho (2010), Imperfectly Credible Disinflation under Endogenous Time-Dependent Pricing, Journal of Money, Credit and Banking, 42 (5), 799-831.

Broadbent, Ben (2014), “Unemployment and the conduct of monetary policy in the UK,” Federal Reserve Bank of Kansas City Economic Symposium, Jackson Hole, Wyoming, August.

Calvo, Guillermo A. (1983), "Staggered Contracts in a Utility-Maximizing Framework." Journal of Monetary Economics 12, September, 383-98.

Carlton, D.W. (1989), "The theory and the facts of how markets clear: is industrial organization valuable for understanding macroeconomics?", in: R. Schmalensee and R.D. Willig, eds., Handbook of lndustrial Organization, vol. 1 (North-Holland, Amsterdam), 909-946. 
Carvalho, Carlos and Felipe Schwartzman (2015), “Selection and monetary non-neutrality in time-dependent pricing models,” Journal of Monetary Economics, 2015, 76 (C), 141156.

Chari, V.V., Kehoe, P., McGrattan, E., (2000), Sticky price models of the business cycle: Can the contract multiplier solve the persistence problem? Econometrica, 68 (5), 1151-1180.

Chari, V.V., Patrick J. Kehoe, and Ellen R. McGrattan (2009) “New Keynesian Models: Not Yet Useful for Policy Analysis,” American Economic Journal: Macroeconomics, 1:1, 242266.

Cecchetti, S.G. (1984), "Indexation and incomes policy: a study of wage adjustment in unionized manufacturing", Journal of Labor Economics, 5:391-412.

Cecchetti, S.G. (1986), "The frequency of price adjustment: a study of newsstand prices of magazines", Journal of Econometrics, 31:255-274.

Christiano, Lawrence, Martin Eichenbaum, and Charles Evans. (2005). "Nominal Rigidities and the Dynamic Effects of a Shock to Monetary Policy" Journal of Political Economy 113, 1: 1-45.

Christiano, Lawrence J. Martin S. Eichenbaum and Mathias Trabandt (2013) “Unemployment and Business Cycles,” Unpublished working paper, Northwestern University, July 19 Dixon, Huw and Engin Kara (2005), “Persistence and Nominal Inertia in a Generalized Taylor Economy; How Longer contracts dominate Shorter Contracts,” European Central Bank, Working paper, No. 489.

Dixon, Huw and Engin Kara (2006), "How to Compare Taylor and Calvo Contracts: A Comment on Michael Kiley,” Journal of Money, Credit and Banking 38 (4), 1119-1126. 
Dixon, Huw and Engin Kara (2011), “Contract Length Heterogeneity and the Persistence of Monetary Shocks in a Dynamic Generalized Taylor Economy,” European Economic Review, 55, 280-292.

Dixon, Huw and Herve le Bihan (2012), “Generalised Taylor and Generalised Calvo Price and Wage Setting; Micro-Evidence with Macro Implications,” The Economic Journal, 122, (May) 532-554.

Dotsey, Michael, Robert G. King, Alexander L. Wolman (1999), “State-Dependent Pricing and the General Equilibrium Dynamics of Money and Output," Quarterly Journal of Economics, 114 (2), May, 655-690.

Dutta S., Levy D., Bergen M. (2002), Price flexibility in channels of distribution: evidence from scanner data. Journal of Economic Dynamics and Control 26:1845-1900.

Edge, Rochelle (2002), “The Equivalence of Wage and Price Staggering in Monetary Business Cycle Models,” Review of Economic Dynamics 5, 559-585.

Erceg, Christopher, Dale Henderson, and Andrew Levin (2000), “Optimal Monetary Policy with Staggered Wage and Price Contracts,” Journal of Monetary Economics, 46 (2) October, 281-313.

Fabiani, Silvia, Martine Druant, Ignacio Hernando, Claudia Kwapil, Bettina Landau, Claire Loupias, Fernando Martins, Thomas Mathä, Roberto Sabbatini, Harald Stahl and Ad Stokman (2006), "What Firms' Surveys Tell Us about Price-Setting Behavior in the Euro Area," International Journal of Central Banking, Special Issue on Staggered Pricing Models Face the Facts. 5 (3), 3-47.

Fischer, Stanley (1977), Long-Term Contracts, Rational Expectations, and the Optimal Money Supply Rule, Journal of Political Economy, 85 (1), February, 191-205. 
Fregert, K., and L. Jonung (1986), "Monetary regimes and the length of wage contracts: Sweden 1908-1995", Working paper 1998-3, University of Lund.

Friedman, Milton (2010), “Trade-offs in Monetary Policy” in David Laidler's Contributions to Economics, Palgrave MacMillan, 2010, London.

Fuhrer Jeffrey C. (2006), “Intrinsic and Inherited Inflation Persistence,” International Journal of Central Banking, Special Issue on Staggered Pricing Models Face the Facts, 5(3), 49-86.

Fuhrer, Jeffrey C. and George R. Moore (1995), “Inflation Persistence,” Quarterly Journal of Economics, 110:1, 127-159.

Gali, Jordi and Mark Gertler (1999), "Inflation Dynamics: A Structural Econometric Analysis,” Journal of Monetary Economics, 44, 195-222.

Gali, Jordi, Mark Gertler, and J. D. Lopez-Salido (2005), "Robustness of the Estimates of the Hybrid New Keynesian Phillips Curve,” Journal of Monetary Economics, 52:1107-1118.

Gertler, Mark and John Leahy (2008), “A Phillips Curve with an Ss Foundation,” Journal of Political Economy, 116, 3.

Gertler, Mark., L. Sala, L and A.Trigari (2008), “An Estimated Monetary DSGE Model with Unemployment and Staggered Nominal Wage Bargaining,” Journal of Money, Credit and Banking 40 (8), 1713-1764.

Geweke, John (1999). "Using Simulation Methods for Bayesian Econometric Models: Inference, Development and Communication," Econometric Reviews 18: 1-126.

Golosov, Mikhail and Robert E. Lucas Jr. (2007), “Menu Costs and Phillips Curves,” Journal of Political Economy, 115 (2), 271-199.

Gordon, R.J., 1982. Discussion. In: Monetary Policy Issues for the 1980s. Federal Reserve Bank of Kansas City, Symposium, Jackson Hole Wyoming. 
Gray, Jo Anna (1976), "Wage indexation: A Macroeconomic Approach," Journal of Monetary Economics, Elsevier, 2 (2), 221--235, April.

Guerrieri, Luca (2006 “Inflation Persistence of Staggered Contracts” Journal of Money, Credit, and Banking 38 (2) (March), 483-494.

Hall, Robert (2005), "Employment Fluctuations with Equilibrium Wage Stickiness. American Economic Review 95 (1), 50-65.

Hume, David (1742) “On Money,” Part II, Essay III, paragraph 7 of his Essays, Moral, Political, and Literary, Liberty Fund Books, online http://www.econlib.org/library/LFBooks/Hume/hmMPL.html

Kara, Engin (2010). “Optimal Monetary Policy in the Generalized Taylor Economy,” Journal of Economic Dynamics and Control, 34, 2023-2037.

Kara, Engin (2015), “The reset inflation puzzle and the heterogeneity in price stickiness,” Journal of Monetary Economics, Volume 76, November, 29-37.

Kashyap, A.K. (1995), "Sticky prices: new evidence from retail catalogues", Quarterly Journal of Economics, 110:245-274.

Kehoe, Patrick and Virgiliu Midrigan (2010), “Prices are Sticky After All,” NBER Working Paper 16364

Kiley, Michael (2002). "Price Adjustment and Staggered Price-Setting," Journal of Money, Credit and Banking, 34, 283-298.

King, Mervyn (1999) “Challenges for Monetary Policy: New and Old,” in New Challenges for Monetary Policy, Federal Reserve Bank of Kansas City Jackson Hole.

King, Mervyn (2012), “Twenty years of Inflation Targeting,” Stamp Memorial Lecture, London School of Economics, London, October 9. 
Klenow, Peter and Oleksiy Kryvtsov (2008), “State Dependent versus Time Dependent Pricing,” Quarterly Journal of Economics, August, 72 (2), 863-904.

Klenow, Peter and Benjamin Malin (2011) “Microeconomic Evidence on Price Setting,” in Benjamin Friedman and Michael Woodford (Eds.), Handbook of Monetary Economics, 3, Elsevier, Amsterdam.

Knell, Markus (2010), “Nominal and Real Wage Rigidities in Theory and in Europe.” European Central Bank, Working paper series.

Lach, S., and D. Tsiddon (1996), "Staggering and synchronization in price-setting: evidence from multiproduct firms", American Economic Review 86 (December): 1175-1196.

Lamo, Ana and Frank Smets (2009) "Wage Dynamics in Europe: Final Report of the Wage Dynamics Network (WDN),” December 4. https://www.ecb.europa.eu/home/pdf/wdn_finalreport_dec2009.pdf?68e28b96d494632f2 $\underline{7900 \mathrm{~b} 1 \mathrm{c} 453586 \mathrm{c} 4}$

Le Bihan, Hervé, Jérémi Montornès, and Thomas Heckel (2012), "Sticky Wages: Evidence from Quarterly Microeconomic Data." American Economic Journal: Macroeconomics, 4 (3): $1-32$.

Levin, A. (1991), "The macroeconomic significance of nominal wage contract duration," Working Paper No. 91-08 (University of California at San Diego, February).

Lünnemann, Patrick and Ladislav Wintr (2009), “Wages are Flexible, Aren’t They? Evidence from Monthly Micro Wage Data,” Wage Dynamic Network, Working Paper Series, No. 1074, July.

Mankiw, N. G. (2001) "The Inexorable and Mysterious Tradeoff between Inflation and Unemployment," Economic Journal, 117, 1295-328. 
Mankiw, N. Gregory and Ricardo Reis (2001), "Sticky Information Versus Sticky Prices: A Proposal to Replace the New Keynesian Phillips Curve," NBER Working Paper 8290. Musy, Olivier (2006), “Inflation persistence and the Real Costs of Disinflation in Staggered Prices and partial Adjustment Models,” Economics Letters, 91, 50-55.

Nakamura, Emi and Jón Steinsson ( 2008), "Five Facts about Prices: A Reevaluation of Menu Cost Models,” Quarterly Journal of Economics, MIT Press, 123 (4), 1415-1464, November.

Nekarda, Christopher J. and Valerie A. Ramey (2013) “The Cyclical Behavior of the Price-Cost Markup,” University of California, San Diego.

Okun, A.M. (1981), Prices and Quantities: A Macroeconomic Analysis (Brookings Institution, Washington, DC).

Olivei, Giovanni and Silvana Tenreyro (2010), “Wage Setting Patterns and Monetary Policy: International Evidence,” Journal of Monetary Economics, 57, 785-802.

Phelps, Edmund and John B. Taylor (1977), “Stabilizing Powers of Monetary Policy under Rational Expectations,” Journal of Political Economy, 85 (1), February, 163-190

Ravenna, Federico and Carl Walsh (2008), “Vacancies, Unemployment, and the Phillips Curve,” European Economic Review, 52, 1494-1521.

Romer, David (2012), Advanced Macroeconomics, Fourth Edition, McGraw-Hill, New York Schorfheide, Frank (2000). "Loss Function Based Evaluation of DSGE Models." Journal of Applied Econometrics 15, 6: 645-670.

Sigurdsson, Jósef and Rannveig Sigurdardottir (2011), 'Evidence of Nominal Wage Rigidity and Wage Setting from Icelandic Microdata,” Working Paper No. 55, Central bank of Iceland 
Sigurdsson, Jósef and Rannveig Sigurdardottir (2016), “Time-dependent or state-dependent wage-setting? Evidence from periods of macroeconomic instability,” Journal of Monetary Economics, 78, 50-66.

Smets, Frank and Raf Wouters. (2003), "An Estimated Dynamic Stochastic General Equilibrium Model of the Euro Area," Journal of the European Economic Association 1 (5), 11231175.

Smets, Frank and Raf Wouters. (2007). "Shocks and Frictions in U.S. Business Cycles: Bayesian DSGE Approach." American Economic Review 97 (3), 506-606.

Stigler, G., and J. Kindahl (1970), The Behavior of Industrial Prices, NBER General Series, No. 90 (Columbia University Press, New York).

Svensson, L.E.0. (1986), "Sticky goods prices, flexible asset prices, monopolistic competition, and monetary policy", Review of Economic Studies 52, 385-405.

Taylor, John B. (1979a) “Estimation and Control of a Macroeconomic Model with Rational Expectations,” Econometrica, 47 (5), September, 1267-1286, Reprinted in R.E. Lucas and T.J. Sargent (Eds.) Rational Expectations and Econometric Practice, University of Minnesota Press, 1981.

Taylor, John B. (1979b), “Staggered Wage Setting in a Macro Model,” American Economic Review, 69 (2), May 1979, 108-113. Reprinted in N. Gregory Mankiw and David Romer (Eds.) New Keynesian Economics, MIT Press, Cambridge, 1991.

Taylor, John B. (1979c), “An Econometric Business Cycle Model with Rational Expectations: Some Estimation Results,” Working Paper, Columbia University, June http://web.stanford.edu/ johntayl/Onlinepaperscombinedbyyear/1979/An_Econometric 


\section{Business_Cycle_Model_with_Rational_Expectations-Some_Estimations_Results-}

\section{9.pdf}

Taylor, John B. (1980), “Aggregate Dynamics and Staggered Contracts,” Journal of Political Economy, 88 (1), February, 1--23.

Taylor, John B, (1982), “The Role of Expectations in the Choice of Monetary Policy,” in Monetary Policy Issues for the 1980s, Federal Reserve Bank of Kansas City Economic Symposium, Jackson Hole, Wyoming, August.

Taylor, John B. (1983), “Union Wage Settlements During a Disinflation,” American Economic Review, 73 (5), December, 981-993.

Taylor, John B. (1993), Macroeconomic Policy in a World Economy: From Econometric Design to Practical Operation, W.W. Norton, New York, 1993.

Taylor, John B. (1999), “Staggered Price and Wage Setting in Macroeconomics” in John B. Taylor and Michael Woodford (Eds.) Handbook of Macroeconomics, North-Holland, Elsevier, 1, Part 2, 1009-1050.

Taylor, John B. (2000), "Low Inflation, Pass-Through, and the Pricing Power of Firms,” European Economic Review, 44 (7), 1389-1408.

Taylor, John B, (2007), “Thirty-five Years of Model Building for Monetary Policy Evaluation: Breakthroughs, Dark Ages, and a Renaissance,” Journal of Money Credit and Banking, Supplement to Vol. 39, No. 1 (February), 193-201.

Taylor, John B. and Volker Wieland (2012), “Surprising Comparative Properties of Monetary Models: Results from a New Model Data Base,” Review of Economics and Statistics, 94 (3), August, 800-816. 
Walsh, Carl E. (2010), Monetary Theory and Policy, Third Edition, The MIT Press, Cambridge, Massachusetts

Wieland, Volker, Tobias Cwik, Gernot J. Müller, Sebastian Schmidt and Maik Wolters, "A New comparative approach to macroeconomic modeling and policy analysis", Journal of Economic Behavior and Organization, August 2012, Vol. 83, 523-541.

Wieland, Volker, Elena Afanasyeva, Meguy Kuete, Jinhyuk Yoo (2016) “New Methods for Macro-Financial Model Comparison and Policy Analysis," in Handbook of Macroeconomics, Volume2, Elsevier, Amsterdam.

Woodford, Michael (2003), Interest and Prices, Princeton University Press, Princeton, New Jersey. 